\title{
Anti-Inflammatory Activity of Cinnamon Bark Oil (Cinnamomum burmannii (Nees \& T. Nees) Blume from Lombok Timur Indonesia
}

\author{
Budiastuti ${ }^{1}$, Rosy Dwi Nurcholida ${ }^{2}$, Riesta Primaharinastiti ${ }^{2}$, Sukardiman ${ }^{2, *}$
}

Budiastuti ${ }^{1}$, Rosy Dwi

Nurcholida², Riesta

Primaharinastiti ${ }^{2}$, Sukardiman ${ }^{2, *}$

'Doctoral Program Faculty of Pharmacy, Universitas Airlangga, Surabaya, INDONESIA ${ }^{2}$ Department of Pharmaceutical Sciences, Faculty of Pharmacy, Universitas Airlangga, Surabaya, INDONESIA.

\section{Correspondence}

\section{Sukardiman}

Department of Pharmaceutical Sciences, Faculty of Pharmacy, Universitas Airlangga, Surabaya, INDONESIA.

E-mail: maman_ht@yahoo.com

History

- Submission Date: 05-04-2021;

- Review completed: 21-05-2021;

- Accepted Date: 02-06-2021.

DOI : 10.5530/pj.2021.13.130

Article Available online http://www.phcogj.com/v13/i4

\section{Copyright}

(c) 2021 Phcogj.Com. This is an openaccess article distributed under the terms of the Creative Commons Attribution 4.0 International license.

\begin{abstract}
Introduction: Research related to alternative medicine from natural ingredients that can relieve the effects of inflammation is important, especially to reduce the unwanted side effects of antiinflammatory drugs. Cinnamomum burmannii (Nees \& T. Nees) Blume is a native Indonesian species which contains essential oils and reported for its anti-inflammatory effect. Therefore, this research was conducted to determine the metabolite profile and anti-inflammatory effect of essential oil from the bark of $C$. burmannii (CBO) from Lombok Timur Regency. Methods: The metabolite profile of CBO was determined using Gas Chromatography-Mass Spectra (GCMS). The anti-inflammatory test was conducted used male Wistar rats. A total of 30 male rats were divided into 5 groups, each group consisting of 6 rats. Rats were injected with carrageenan $1 \% / 100 \mu \mathrm{l} /$ paw which had previously been given oral CBO at a dose of $30,60,90$ $\mathrm{mg} / \mathrm{kg} \mathrm{BW}$. Paw swelling was measured at 1, 2, 3, 4 and 5 hours after injection. The volume of edema was measured and the animals were sacrificed. The left leg was cut and preserved as material for Hematoxylin Eosin (HE) and Immunohistochemistry (IHC) preparations. The variables taken were the percentage of inhibition edema, the number of inflammatory cells by HE and the amount of TNF- $\alpha$ by IHC staining. Results: The results showed that there was a difference between negative control and positive control in the number of inflammatory cells and TNF- $\alpha$ observed in rat's paw edema. The number was less in the positive control. Likewise, when administering $\mathrm{CBO}(60 \mathrm{mg} / \mathrm{kg} \mathrm{BW}$ and $90 \mathrm{mg} / \mathrm{kg} \mathrm{BW})$ the number of inflammatory cells and TNF- $\alpha$ was lower than the negative control. Conclusion: It can be concluded that CBO from Lombok Timur can be used as a natural anti-inflammatory agent.
\end{abstract}

Key words: Cinnamomum burmannii, Metabolites profile, Inflammatory cells, TNF- $\alpha$, Immunohistochemical staining.

\section{INTRODUCTION}

Inflammation is the response of the human or animal body and the complex interactions between immune cells and mediator molecules ${ }^{1}$. This is a common problem in society as a result of lifestyle and health problems. Inflammation can play an important role in the pathogenesis of various types of acute and chronic diseases such as cardiovascular disease, neurodegenerative diseases, obesity, and type 2 diabetes mellitus. Pharmacotherapy for inflammatory conditions is still dominated by the use of non-steroidal anti-inflammatory drugs (NSAIDs). NSAIDs comprise a group of non-selective and selective NSAIDs. Non-selective NSAIDs work to inhibit the cyclooxygenase enzymes (COX-1 and COX2) which decrease prostaglandin production. The inhibitor group works by inhibiting the COX-2 enzyme. NSAIDs are commonly used to relieve pain and inflammation caused by various types of arthritis and musculoskeletal disorders. Although effective in reducing pain and inflammation, NSAIDs cause side effects including serious gastrointestinal toxicities such as gastric ulcers and bleeding ${ }^{2}$. Some NSAIDs that work to inhibit COX-2 induce an increase in blood pressure, increasing the risk of blockages that lead to heart failure, clotting, and heart muscle death ${ }^{3}$.

Research that has linked alternative medicine to natural ingredients that can relieve the effects of inflammation is important, especially to reduce the unwanted side effects of anti-inflammatory drugs $^{4,5}$. Trans-Cinamaldehyde, which is a major component of Cinnamomum spp essential oil, has been studied to modulate systemic inflammatory response syndrome (SIRS) by activating the potential mechanism of Ankyrin 1-dependent and transient receptor-independent (TRPA1) ${ }^{6}$. Other researchers stated that the essential oil from Cinnamomum zeylanicum bark significantly inhibited the production of several inflammatory biomarkers ${ }^{7}$. Cinnamomum burmannii (Nees \& T. Nees) Blume is a native Indonesian species containing transcinnamaldehyde ${ }^{8}$. The high trans-cinnamaldehyde levels in cinnamon are expected to have antiinflammatory effects. The inflammatory response induces increased permeability of the endothelial cell layer and entry of leukocytes into the interstitium and releases cytokines such as interleukins and tumor necrosis factor- $\alpha$ (TNF- $\alpha$ ). It also stimulates the activity of several enzymes (oxygenase, nitric oxide synthase, peroxidase, etc.), as well as the metabolism of arachidonic acid 9 . The pharmacological effect of medicinal preparations with active ingredients of

Cite this article: Budiastuti, Nurcholida RD, Primaharinastiti R, Sukardiman. Anti-Inflammatory Activity of Cinnamon Bark Oil (Cinnamomum burmannii (Nees \& T. Nees) Blume from Lombok Timur Indonesia. Pharmacogn J. 2021;13(4): 1005-1013. 
plant origin such as the bark of C. burmannii is influenced by active compounds, namely secondary metabolites. Therefore we need a metabolite profile. This research was conducted using essential oil of C. burmannii stem bark from Lombok Timur, Nusa Tenggara Barat Province, which is one of the cinnamon-producing districts located on the eastern tip of the island of Lombok.

The profile of secondary metabolites in essential oils was carried out using Gas Chromatography-Mass Spectra (GC-MS) analysis because it is one of the main analysis platforms for metabolites with low polarity, volatility, high resolution, good reproducibility and metabolite standards ${ }^{10}$. Metabolite profile is a very complex data information describing almost all chemical characteristics in it. This research begins with the standardization and specification of essential oils and the analysis of the metabolite profile of C. burmannii bark oil (CBO). Furthermore, the anti-inflammatory test was carried out at three doses of $\mathrm{CBO}$. The data obtained were used to calculate the $\mathrm{IC}_{50}$ and determine the dose. The anti-inflammatory test was carried out in vivo with the Paw test and histopathological observations (the number of inflammatory cells and TNF- $\alpha$ in the sole of the foot tissue). Therefore, analysis of metabolite profile and in vivo test of anti-inflammatory activity of CBO from Lombok Timur was carried out.

\section{MATERIALS AND METHODS}

\section{Plant material}

This research was conducted using essential oils from the bark of C. burmannii aged between 10 years and 12 years from Lombok Timur which were harvested on May, 2018 and dried in an open space protected from direct sunlight to LOD (Loos of drying) $<12 \%$. Identification was carried out by LIPI (Indonesian Institute of Sciences) Purwodadi Botanical Garden (No. 716/IPH.06/HM/V/2018) and has met the Indonesian Herbal Pharmacopoeia standard.

\section{Chemicals}

Distilled water, $\mathrm{NaCl}, \mathrm{Na}_{2} \mathrm{SO}_{4}$, trans-Cinnamaldehyde compounds $\geq 98 \%$ (Merck), dichloromethane (Merck), Carrageenan (Merck), Ibuprofen, Ketamine, xylazine base $20 \mathrm{mg} / \mathrm{ml}$ brand Xyla, $0.9 \%$ sodium cloride Intravenous Infusion B.P. Otsu-NS brand, formaldehyde buffer, TNF- $\alpha$ monoclonal antibody E-AB-22159 Elabscience Biotechnology Inc.

\section{Experimental animal}

This study used male rat (Rattus novergicus) Wistar strain with the criteria of 3 months' age, body weight of 180-220 g, and in a good health (clean hair, active movement, and clear eyes). Rats were obtained from the Pharmacology Laboratory, Faculty of Medicine, Universitas Airlangga. Certificate of Ethical Clearance was obtained from the Faculty of Veterinary Medicine, Universitas Airlangga No: 2.KE.075.05.2019.

\section{Essential oil distillation}

Essential oil was obtained by water and steam distillation. As much as $3 \mathrm{~kg}$ of C. burmannii bark, ground into a mess 8 size. The powder was then distilled over a bath using 5 liters of water. The bath has been assembled with a condensor, ensuring that there is no leakage and circulating properly. Distillate was stored for up to 6 hours, counting from the first distillate drop and carried out 3 replications ${ }^{11}$. The essential oil was separated from the aqueous phase using a separating flask. Each liter of water phase was added 15 grams of $\mathrm{NaCl}$. The oil phase was then separated. The essential oil collected then added with anhydrous $\mathrm{Na}_{2} \mathrm{SO}_{4}$.
Table 1: GC-MS analysis condition of CBO.

\begin{tabular}{|c|c|}
\hline Condition GC-MS & Explanation \\
\hline Column & $\begin{array}{l}\text { Agilent column } 19091 \mathrm{~S}-433 \mathrm{UI} \text { HP-5ms Ultra } \\
\text { Inert }-60^{\circ} \mathrm{C}-325^{\circ} \mathrm{C}\left(350^{\circ} \mathrm{C}\right)\end{array}$ \\
\hline Column dimention & $30 \mathrm{~m} \times 250 \mu \mathrm{m} \times 0.25 \mu \mathrm{m}$ \\
\hline Run time & $30 \mathrm{~min}$ \\
\hline Initial oven temperature & $100^{\circ} \mathrm{C}$ \\
\hline Hold time & $2 \min$ \\
\hline Post run & $0^{\circ} \mathrm{C}$ \\
\hline Program rate & $5^{\circ} \mathrm{C}$ value $200^{\circ} \mathrm{C}$ \\
\hline Hold time & $8 \mathrm{~min}$ \\
\hline Equilibration time & $0.1 \mathrm{~min}$ \\
\hline Max temperature & $325^{\circ} \mathrm{C}$ \\
\hline front injector syringe size & $10 \mu \mathrm{l}$ \\
\hline injection volume & $1 \mu \mathrm{l}$ \\
\hline front ss $\mathrm{He}$ & in split mode \\
\hline heater & $300^{\circ} \mathrm{C}$ \\
\hline pressure & 10,523 psi \\
\hline total flow & $14 \mathrm{ml} / \mathrm{min}$ \\
\hline split ratio & $10: 1$ \\
\hline out MSD initial & $100^{\circ} \mathrm{C}$ \\
\hline pressure & 10,523 psi \\
\hline flow & $1 \mathrm{ml} / \mathrm{min}$ \\
\hline average velocity & $37,293 \mathrm{~cm} / \mathrm{sec}$ \\
\hline hold time & $1.3407 \mathrm{~min}$ \\
\hline
\end{tabular}

\section{Metabolite profiles of $C$. burmannii bark essential oil (CBO)}

The metabolite profile of $\mathrm{CBO}$ was determined using GC-MS. The sample was diluted with methylene dichloride $(10 \mathrm{mg} / \mathrm{mL})$ and $1.0 \mu \mathrm{L}$ was injected for analysis. Component identification was carried out by matching the mass spectra recorded with the mass spectrum standards from the National Institute of Standard and Technology Library (NIST05.LIB). GC-MS analysis conditions as seen on Table 1.

\section{In vivo anti-inflammatory activity test}

A total of 30 male rats Wistar were used throughout this study housed under conditions of optimum light, temperature and humidity $(12 \mathrm{~h}$ light-dark cycle, $27^{\circ} \mathrm{C} \pm 2^{\circ} \mathrm{C}, 65-75 \%$ humidity), with food and water provided ad libitum. Rats were divided into 5 groups; each group consist of 6 rats $^{12}$. Each rat's left leg was given a permanent ink mark right on the lateral malleolus. Observation begins with all animals measured paw volume as volume $t=0$. Group 1 as negative control treated with $1 \%$ CMC-Na solution, group 2 as positive control treated with ibuprofen at a dose of $27 \mathrm{mg} / \mathrm{kg}$, Group 3, 4, and 5 treated with

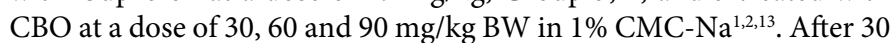
min of treatment, experimental animals were injected with carrageenan $1 \% / 100 \mu \mathrm{l} /$ paw (carrier $0.9 \%$ sterile $\mathrm{NaCl}$ ) using a 26 -gauge needle. Furthermore, measurements of paw swelling were carried out at 1 , $2,3,4$, and 5 hours using a plethysmometer model 7141 UGO Basile S.R.I. Italy ${ }^{14,15}$. After measuring the volume of edema, the animals were sacrificed by injecting ketamine and xylazine. The left foot was cut and preserved in formaldehyde buffer liquid as material for HE and IHC preparations ${ }^{16}$.

\section{Histological examination}

Measurement of the number of inflammatory cells was conducted by HE technique. The paw tissues were separated and fixed in neutral buffered formalin, subsequently embedded in paraffin, sliced (3-5 $\mu \mathrm{m})$ and stained using hematoxylin and eosin for histopathological examination. This histopathological examination is intended to 
determine the number of inflammatory cells in the paw tissue by the researcher and two anatomical pathologists. Inflammatory cells count data were obtained by counting all the inflammatory cells found in five field of view at 400x magnification. All these examinations use a Nikon H600L light microscope equipped with a 300 megapixel DS Fi2 digital camera and the Nikkon Image System image processing software.

\section{Examination of TNF-a expression by IHC}

The staining process was first carried out before examining TNF- $\alpha$ expression under a light microscope by researcher and two anatomical pathologists. The slides were washed with PBS $\mathrm{pH} 7.4$ once for 5 minutes then endogenous peroxide blocking was carried out using $\mathrm{H}_{2} \mathrm{O}_{2} 3 \%$ twice for 5 minutes. Furthermore, slides were washed using PBS pH of 7.4 twice, for 5 minutes. The unspecified protein was blocked using 5\% FBS containing $0.25 \%$ Triton X-100. Before and after the slides were incubated using anti-TNF- $\alpha$, for 60 minutes, the slides were washed first using PBS pH 7.4 twice, for 5 minutes. After that, incubation was performed using biotinylated link (yellow) drops for 30 minutes. Washing using PBS pH 7.4 three times for 5 minutes. Furthermore, the slides were dripped with DAB (Diamino benzidine) chromogen, diluted $2 \%$ with DAB plus substrate and incubated for 6-10 minutes, then washed using PBS pH 7.4 twice, for 5 minutes. The next step is washing using aquadest dipping for 5 minutes. Counterstaining using Mayer Hematoxilin and incubated for 10 minutes and washed using tap 2 to dry and dry before being mounted using a dummy and covered with a glass cover. This histopathological examination was intended to determine the expression of TNF- $\alpha$ in the healing areas of the paw tissue. The TNF- $\alpha$ expression in each sample was assessed semiquantitatively according to the modified Remmele method ${ }^{17}$, where the Remmele scale Index (Immuno Reactive Score/IRS) is the result of multiplying the percentage score of immunoreactive cells with the color intensity score on the immunoreactive cells (Table 2). The data for each sample is the average IRS value observed at five different fields of view at 1000x magnification. All of these examinations used Nikon H600L light microscope, equipped with a 300 megapixel DS Fi2 digital camera and the Nikkon Image System image processing software ${ }^{17}$. The IRS semiquantitative scale is the result of multiplying the positive cell percentage score $(\mathrm{A})$ and the color reaction intensity score $(\mathrm{B}), \mathrm{IRS}=(\mathrm{A} \times \mathrm{B})$.

\section{Statistical analysis}

Data are expressed as mean \pm standard error of the mean (SEM). Statistical evaluation anti-inflammatory activity testing method was carried out by one-way analysis of variance (ANOVA). Statistical significance is expressed as $P<0.05$. Data were analyzed using the independent-sample t-test from the software product SPSS 24.0. The data obtained was analyzed with the Shapiro-Wilk test to determine the normality of data and analyzed with the Levene test to determine the homogeneity of data. If the data is normally distributed and homogeneous, it is followed by ANOVA test with a confidence level of $95 \%$. The Kruskal-Wallis test was used to analyze the Number of Inflammatory Cells and TNF- $\alpha$ Expression.

\section{RESULTS}

\section{Essential oil distillation}

The results of the distillation of C. burmannii bark powder are listed in Table 3.

\section{Metabolite profiles of $\mathrm{CBO}$}

The composition of $\mathrm{CBO}$ is shown in Figure 1 and Table 4 . The essential oil profile from C. burmannii bark contains more than 41 compounds. The main compound of $\mathrm{CBO}$ is trans-cinnamaldehyde, which is considered as the most dominant one. The other main components are Caryophyllene, Benzen propanal, Linalool, a-Muurolene, $\gamma$-Muurolene, $a$-Terpineol, Isoledene and Eugenol.

\section{Analysis of inhibition of edema}

The carrageenan-induced inflammatory reaction develops in the form of edema with an increase the paw volume to $67 \%$ of baseline volume. The maximum volume of edema was observed in the negative control group at three hours after carrageenan injection. Inhibition of edema due to inflammation caused by carrageenan showed a decrease in the volume of edema in ibuprofen administration and $\mathrm{CBO}$ administration at a dose of $60 \mathrm{mg} / \mathrm{kg} \mathrm{BW}$ and $90 \mathrm{mg} / \mathrm{kg} \mathrm{BW}$ (Table 5). CBO at a dose of $60 \mathrm{mg} / \mathrm{kg}$ and $90 \mathrm{mg} / \mathrm{kg}$ showed anti-inflammatory activity at 1, 2, 3, 4 and 5 hours after carrageenan induction.

\section{The observations of inflammatory cells and TNF- $a$ on HE and IHC preparations}

The observation results showed a decrease in the number of inflammatory cells and TNF- $\alpha$ at a dose of $60 \mathrm{mg} / \mathrm{kg}$ and $90 \mathrm{mg} / \mathrm{kg} \mathrm{BW}$ (Figures 2 and 3, Tables 6 and 7).

\section{DISCUSSION}

The yield of essential oil from the distillation of C. burmannii bark was $0.7078 \pm 0.0379 \%$. Essential oil of CBO contains trans-Cinnamaldehide $46.31 \%$ and a specific gravity of 1.0041 . The carrageenan-induced paw edema model is a suitable test for evaluating anti-inflammatory drugs by assessing the percentage of drug inhibitory effect and has

Table 2: Semi-quantitative Immunoreactive Score (IRS) scale.

\begin{tabular}{ll}
\hline \multicolumn{1}{c}{ A } & \multicolumn{1}{c}{ B } \\
Score $0:$ No positive cells & Score 0 : No color reaction \\
Score $1:$ Positive cells less than $10 \%$ & Score 1: Weak yellowish color intensity \\
Score $2:$ Positive cells range from $11 \%-50 \%$ & Score 2: Medium color intensity (brown) \\
Score $3:$ Positive cells range from $51 \%-80 \%$ & Score 3 : Strong color intensity (dark brown) \\
Score $4:$ Positive cells more than $80 \%$ &
\end{tabular}

Table 3: Specifications of CBO.

\begin{tabular}{|llllll} 
& Rendement & Organoleptic & Specific gravity & Refractive Index & $\begin{array}{l}\text { Trans- } \\
\text { Cinnamaldehyde } \\
\text { Content (\%) }\end{array}$ \\
\hline Essetial Oil & $0.7078 \pm 0.0379$ & $\begin{array}{l}\text { Clear yellow color, } \\
\text { distinctive odor (smell } \\
\text { like cinnamaldehyde) }\end{array}$ & $1.0041 \pm 0.0011$ & $1.5627 \pm 0.0041$ & $45.715 \pm 0.841$ \\
\hline
\end{tabular}


Table 4: GC-MS analysis of the composition of CBO.

\begin{tabular}{|c|c|c|}
\hline No. & Compound name & $\%$ Relative \\
\hline 1 & Eucalyptol & 0.34 \\
\hline 2 & Linalool & 4.19 \\
\hline 3 & Benzen propanal & 5.05 \\
\hline 4 & Endoborneol & 0.48 \\
\hline 5 & Terpinen-4-ol & 0.56 \\
\hline 6 & a-Terpineol & 1.48 \\
\hline 7 & trans-Cinnamaldehyde & 46.31 \\
\hline 8 & Bornyl acetate & 1.01 \\
\hline 9 & 4-ethenyl-4-methyl-3-Cyclohexene & 0.23 \\
\hline 10 & Eugenol & 1.07 \\
\hline 11 & $\alpha$ - Ylangene & 0.63 \\
\hline 12 & Copaene & 2.24 \\
\hline 13 & Aromadendrene & 0.39 \\
\hline 14 & Trans- $\alpha$-Bergamotene & 0.41 \\
\hline 15 & Caryophyllene & 6.71 \\
\hline 16 & Cinnamyl ester Acetic Acid & 1.43 \\
\hline 17 & Isopropyl-dimethyl Hexahydroazulene & 0.26 \\
\hline 18 & Humulene & 1.22 \\
\hline 19 & dimethyl Octahydrophthalene & 0.81 \\
\hline 20 & epi-Bicyclosesquiphellandrene & 0.23 \\
\hline 21 & $\mathrm{\gamma}$-Muurolene & 2.50 \\
\hline 22 & Isoledene & 2.89 \\
\hline 23 & Aromadendrene & 0.45 \\
\hline 24 & $\Delta$-Selinene & 1.10 \\
\hline 25 & a-Muurolene & 3.42 \\
\hline 26 & ß-Bisabolene & 0.99 \\
\hline 27 & hexahydro, 7-dimethyl-1-(metylethyl) Naphthalene & 5.04 \\
\hline 28 & Epizonarene & 0.35 \\
\hline 29 & Cubenene & 0.63 \\
\hline 30 & isopropyl-6-Methyl-1-methylene-tetrahydrophthalene & 1.41 \\
\hline 31 & Caryophyllenyl alcohol & 0.88 \\
\hline 32 & Longifolene & 0.23 \\
\hline 33 & Decahydro methyl-1-methylene-7-methylethyl-Naphthalene & 0.34 \\
\hline 34 & Tetradecanal & 0.76 \\
\hline 35 & 2-acetyl 6 methoxy Naphthalene & 0.46 \\
\hline 36 & 7(11)-diene Selina-3 & 0.27 \\
\hline 37 & di-epi-1,10-Cubenol & 0.46 \\
\hline 38 & T-Cadinol & 0.99 \\
\hline 39 & Copaene & 0.43 \\
\hline 40 & T-Muurulol & 0.83 \\
\hline 41 & Cis- $\alpha$-Copaene & 0.28 \\
\hline
\end{tabular}

Table 5: Mean Percentage of paw edema inhibition in each group.

\begin{tabular}{|c|c|c|c|c|c|c|}
\hline \multirow{2}{*}{ Group } & \multicolumn{6}{|c|}{ Mean percentage of edema inhibition at (\%) } \\
\hline & 0 & $1 \mathrm{~h}$ & $2 \mathrm{~h}$ & $3 h$ & $4 \mathrm{~h}$ & $5 \mathrm{~h}$ \\
\hline Negative Control & 0 & 0 & 0 & 0 & 0 & 0 \\
\hline $\begin{array}{l}\text { Ibuprofen } \\
27 \mathrm{mg} / \mathrm{kg}\end{array}$ & 0 & $40.00 \pm 10.74$ & $30.11 \pm 7.87$ & $71.80 \pm 5.17$ & $77.67 \pm 3.47$ & $88.14 \pm 3.58$ \\
\hline $\mathrm{CBO} 30 \mathrm{mg} / \mathrm{kg}$ & 0 & $6.89 \pm 2.46$ & $3.93 \pm 1.76$ & $24.31 \pm 3.87$ & $40.29 \pm 6.11$ & $53.52 \pm 5.00$ \\
\hline $\mathrm{CBO} 60 \mathrm{mg} / \mathrm{kg}$ & 0 & $15.00 \pm 5.83$ & $20.12 \pm 3.54$ & $29.09 \pm 13.30$ & $70.27 \pm 9.97$ & $84.41 \pm 5.19$ \\
\hline CBO $90 \mathrm{mg} / \mathrm{kg}$ & 0 & $32.50 \pm 5.37$ & $25.72 \pm 2.40$ & $64.23 \pm 8.92$ & $72.57 \pm 4.97$ & $86.07 \pm 8.06$ \\
\hline
\end{tabular}

Table 6: The number of inflammatory cells.

\begin{tabular}{cc} 
Group & Amount of Inflammatory Cells / 5 Field of View \\
\hline Negative control & $713.00 \pm 93.74$ \\
Ibuprofen $27 \mathrm{mg} / \mathrm{kg} \mathrm{BW}$ & $399.67 \pm 187.73$ \\
CBO $30 \mathrm{mg} / \mathrm{kg} \mathrm{BW}$ & $461.67 \pm 69.08$ \\
CBO $60 \mathrm{mg} / \mathrm{kg} \mathrm{BW}$ & $419.67 \pm 173.30$ \\
CBO $90 \mathrm{mg} / \mathrm{kg} \mathrm{BW}$ & $170.67 \pm 75.18$
\end{tabular}




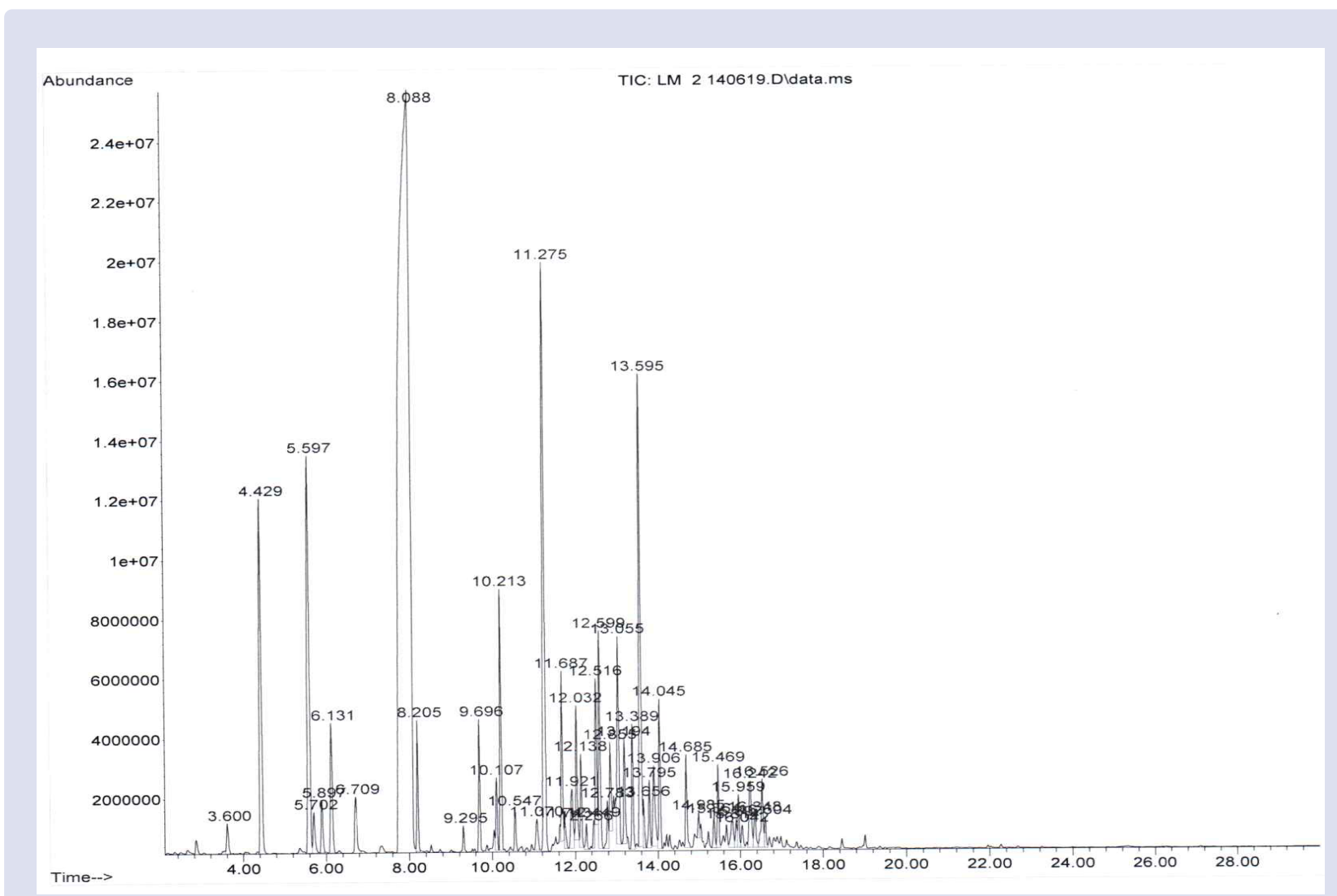

Figure 1: Secondary metabolite components of CBO from Lombok Timur using GC-MS.
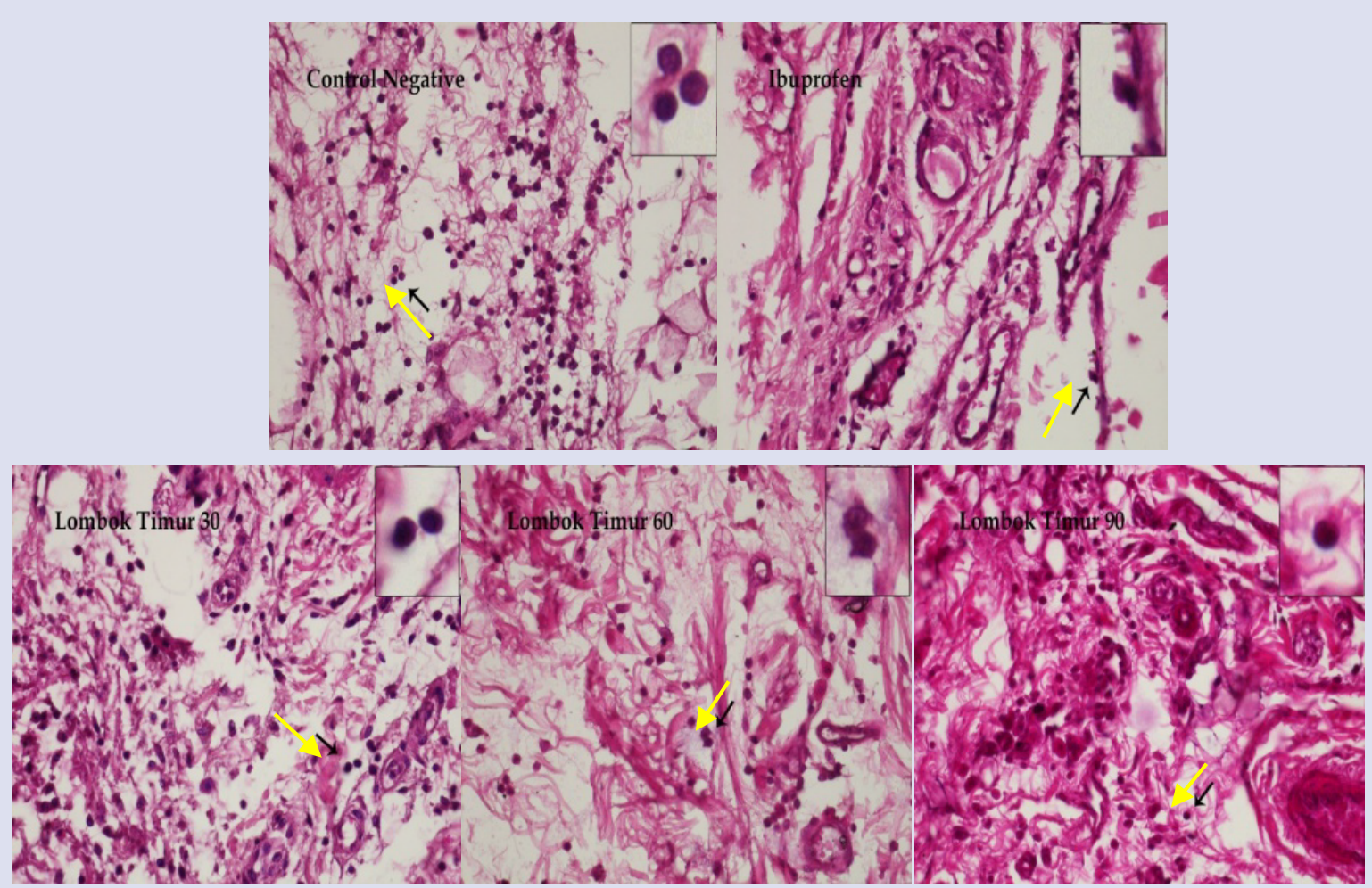

Figure 2: Photomicrographs of the histopathological analysis of paw tissue from rats treated with CMC-Na/negative control (A); Ibuprofen/positive control (B); CBO $30 \mathrm{mg} / \mathrm{kg}$ (C), $60 \mathrm{mg} / \mathrm{kg}$ (D), $90 \mathrm{mg} / \mathrm{kg}$ (E), immunohistochemical staining, 400x magnification; Nikon H600L microscope; 300 megapixel DS Fi2 camera. 


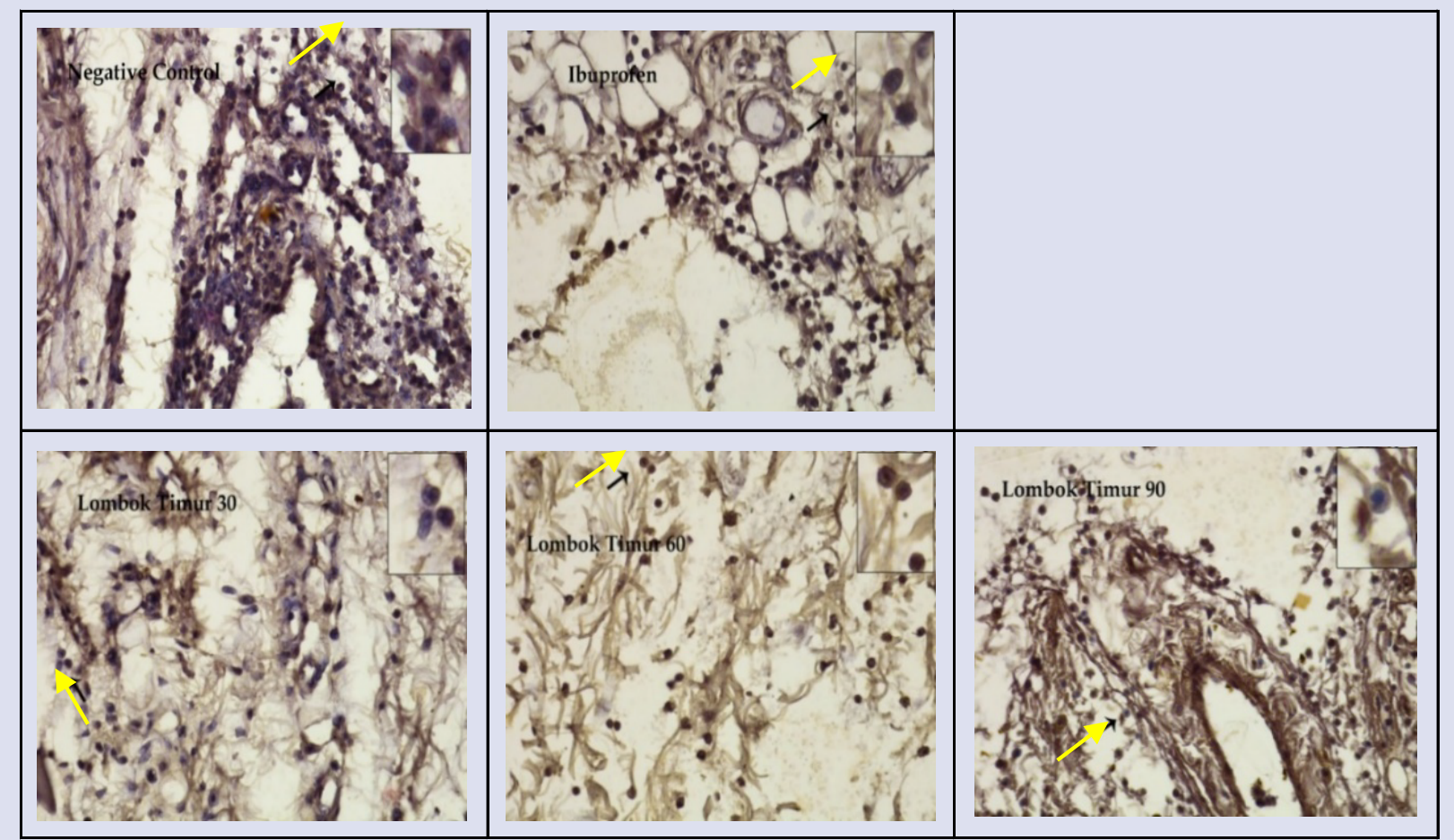

Figure 3: Comparison of TNF-a expression between treatments: CMC-Na/negative control (A); Ibuprofen/positive control (B); CBO 30 mg/ $\mathrm{kg}(C), 60 \mathrm{mg} / \mathrm{kg}(\mathrm{D}), 90 \mathrm{mg} / \mathrm{kg}$ (E), (Inlet: shows TNF-a expression represented by chromogenic brown color in the nucleus and cytoplasm of macrophage cells) (immunohistochemical staining, 400x magnification; Nikon H600L microscope; 300 megapixel DS Fi2 camera).

Table 7: TNF-a value calculation.

$\begin{array}{cc}\text { Groups } & \text { Score } \\ \text { Negative control } & 10.7 \pm 1.30 \\ \text { Ibuprofen } 27 \mathrm{mg} / \mathrm{kg} \mathrm{BW} & 10.5 \pm 0.58 \\ \text { CBO } 30 \mathrm{mg} / \mathrm{kg} \mathrm{BW} & 11.6 \pm 0.69 \\ \mathrm{CBO} 60 \mathrm{mg} / \mathrm{kg} \mathrm{BW} & 10.5 \pm 1.03 \\ \mathrm{CBO} 90 \mathrm{mg} / \mathrm{kg} \mathrm{BW} & 9.2 \pm 2.46\end{array}$

been frequently used to assess the anti-inflammatory effect of natural products $^{18}$. The induced inflammatory reaction of carrageenan develops in the form of edema with an increase in paw volume up to $67 \%$ of the initial volume. The maximum volume of edema was observed in the negative control group at three hours after carrageenan injection. There was inhibition of edema when administering CBO at doses of 30,60, $90 \mathrm{mg} / \mathrm{kg}$ and ibuprofen (Table 5). At doses of 60 and $90 \mathrm{mg} / \mathrm{kg}$ CBO showed anti-inflammatory activity occurred at 1, 2, 3,4 , and 5 hours. The inflammation that occurred in this study was caused by carrageenan and needle wounds that intervened in the tissue. Exudation due to increased vascular permeability is a major cause of acute inflammation. Inflammation serves to avoid injury which in turn will damage cells and body tissues. Inflammation caused by foreign bodies occurs relatively quickly. The maximum swelling rate in the paw that was injected with carrageenan was reached about three hours after carrageenan administration. The maximum swelling volume decreased with $\mathrm{CBO}$ and ibuprofen. Inhibition of edema was seen from the first hour of administration of CBO at doses of $60 \mathrm{mg} / \mathrm{kg}$ and 90 $\mathrm{mg} / \mathrm{kg} \mathrm{BW}$.The results of the normality and homogeneity test of the percentage of edema inhibition data at 1 to 5 hours after carrageenan induction had a $\mathrm{p}$ value $>0.05$. This shows that the standard residual value of the observed data is normally distributed. The percentage of inhibition of edema at 1 to 5 hours has a p value $>0.05$ which indicates that the data is homogeneous. The results of statistical calculations of multiple comparisons one way ANOVA percentage of inhibition at 1 to 5 hours with a dose of $30 \mathrm{mg} / \mathrm{kg}, 60 \mathrm{mg} / \mathrm{kg}$ and $90 \mathrm{mg} / \mathrm{kg} \mathrm{BW}$ showed a significance value $<0.05$, meaning that there was a significant difference between a dose of $30 \mathrm{mg} / \mathrm{kg}$ with $60 \mathrm{mg} / \mathrm{kg}$ and $90 \mathrm{mg} / \mathrm{kg}$ $\mathrm{BW}$. The results of $\mathrm{IC}_{50}$ calculations show that $\mathrm{CBO}$ is able to perform $50 \%$ resistance to edema. The $\mathrm{IC}_{50} \mathrm{CBO}$ value is $74.83 \mathrm{mg} / \mathrm{kg} \mathrm{BW}$.

Carrageenan is a chemical that is effective in releasing inflammatory and proinflammatory mediators (prostaglandins, leukotrienes, histamine, bradykinin, TNF- $\alpha$, etc. $)^{19}$. Tumor necrosis factor- $\alpha$ (TNF- $\alpha)$ is a pro-inflammatory cytokine involved in the formation and continuation of the process. inflammation ${ }^{20}$. TNF- $\alpha$ has many effects, including activation of inflammatory cells and induction of several inflammatory proteins. Inflammatory cell count and TNF- $\alpha$ were observed as indicators of inflammatory response in addition to observations of inhibition of edema.

The inflammatory response begins with the release of inflammatory cells, namely basophils, eosinophils, neutrophils, and some monocytes due to increased vascular permeability that occurs due to contraction and separation of endothelial cells. Analysis of inflammatory cells in HE preparations, namely the paw that were injected with carrageenan in the negative control group showed an accumulation of inflammatory cell infiltration (Figure 2). Tissue previously treated with $\mathrm{CBO}$ or ibuprofen had a decreased number of inflammatory cells compared to controls. The dose given also affects the improvement of inflammatory conditions, it appears that the essential oil dose of $60 \mathrm{mg} / \mathrm{kg} \mathrm{BW}$ is better than $30 \mathrm{mg} / \mathrm{kg} \mathrm{BW}$. 
The number of inflammatory cells observed in paw edema due to carrageenan intervention can show a difference between negative and positive controls, that is, less in positive controls. Likewise, when administering $\mathrm{CBO}$ at a dose of $60 \mathrm{mg} / \mathrm{kg} \mathrm{BW}$ and $90 \mathrm{mg} /$ $\mathrm{kg} \mathrm{BW}$, the number of inflammatory cells was relatively lower than the negative control. The amount of TNF- $\alpha$ showed a decrease in rats given $\mathrm{CBO}$ or ibuprofen. The data obtained from this study indicate that $\mathrm{CBO}$ can inhibit the increase in edema volume which indicates an inhibition of prostaglandin release. Local inflammation of the feet involves bradykinin, a prostaglandin that induces vasodilation and increases vascular permeability. Macrophages release cytokines (IL-1, IL-6, TNF- $\alpha$ ) which cause local and systemic changes. IL-1 and TNF- $\alpha$ trigger macrophages to produce cytokines that act as neutrophil inflows. IFN- $\gamma$ and TNF- $\alpha$ activate macrophages to enhance phagocytosis. The histopathological features paw assessed by the appearance of IHC TNF- $\alpha$ staining can indicate the severity of inflammation. A decrease in the amount of TNF- $\alpha$ can be used as an indicator of decreasing the severity of inflammation1. The largest amount of TNF- $\alpha$ was in the negative control group. Improvements in the histopathological image of paw tissue preparations assessed based on the appearance of IHC TNF- $\alpha$ staining were found in the group that received ibuprofen as a positive control or the group that was given $\mathrm{CBO}$. Trans-Cinnamaldehyde can suppress the production of proinflammatory cytokines ${ }^{21}$. The sequence of images for improvement in HE and IHC observations did not show the exact same sequence as the edema test but in general, $\mathrm{CBO}$ administration showed a decrease in the number of inflammatory cells and TNF- $\alpha$. A decrease in edema volume, a decrease in the number of inflammatory cells and TNF- $a$ can be data that can be used as an indicator that the administration of essential oils has an anti-inflammatory effect. Inhibition of TNF- $a$ release may reduce the severity of inflammation ${ }^{22}$. Thus, the essential oil of C. burmannii bark has been shown to have an acute antiinflammatory effect in experimental animal rats.

\section{CONCLUSION}

The findings mentioned above suggest that increased use of essential oils from C. burmannii bark can reduce sides effect of inflammation on paw of rats. To our knowledge, this is the first report of C. burmannii bark oil regarding to the anti-inflammatory activity in rats. C. burmannii bark oil can contribute to decrease the number of inflammatory cells and TNF- $\alpha$. A decrease in the volume of edema, a decrease in the number of inflammatory cells and TNF- $\alpha$ can be used as indicators that the administration of essential oils has an anti-inflammatory effect and provide therapeutic options that are beneficial for reducing an acute anti-inflammatory effect in rat as experimental animals.

\section{ACKNOWLEDGMENT}

The authors are grateful to Kementrian Riset, Teknologi dan Pendidikan Tinggi Indonesia, Doctoral Dissertation Research in Fiscal Year 2019 Grant No: 1520/UN3/2020.

\section{REFERENCES}

1. Sun, L , Zong S., Li J., Lv Y. , Liu L., Wang Z, The essential oil from the twigs of Cinnamomum cassia Presl alleviates pain. Journal of Ethnopharmacology. 2016; 22 October; 194, pp. 904-912.

2. Vetal, S., Bodhankar, S. L., Mohanb, V. \& Thakurdesai, P. A., Anti-inflammatory and Anti-arthritic Activity of type-a Procyanidine Polyphenols from Bark of Cinnamomum zeylanicum in rats. Food Science and Human Wellness. 2013; 2, p. 59-67.

3. Gunawardena, Dhanuska,Karunaweera, Niloo, lee, Samiuela. Antiinflammatory Activity of Cinnamon (C. zeylanicum and C. cassia) Extracts -identification of E-cinnamaldehyde and O-methoxy cinnamaldehyde As The Most Potent Bioactive Compounds. The Royal Society of Chemistry. Food Funct. 2015; 6(3):910-9
4. Ghasemian, M., Owlia, S. \& Owlia, M. B., Review of AntiInflammatory Herbal Medicines. Advances in Pharmacological Sciences. 2016; January, 1(Article ID 9130979), pp. 1-11

5. Sá, R. d. C. d. S. e. \& Nalone, L. A Review on Anti-Inflammatory Activity of Phenylpropanoids. Molecules. 2014; 19, pp. 1459-1480.

6. Mendes, S. J. Mendes, Saulo J.F.; Sousa, Fernanda I.A.B.; Pereira, Domingos M.S.; Ferro, Thiago A.F.; Pereira, lone C.P.; Silva, Bruna L.R.; Pinheiro, Aruanã J.M.C.R. et al. Cinnamaldehyde modulates LPS-induced systemic inflammatory response syndrome through TRPA1-dependent and independent mechanisms. International Immunopharmacology, 2016; 34, p. 60-70

7. Han , X. \& Parker, T. L. Antiinflammatory Activity of Cinnamon (Cinnamomum zeylanicum) Bark Essential Oil in. Phytotherapy Research, 2017; 31, p. 1034-1038

8. Budiastuti, et al. Standardization Bark of Cinnamomum burmannii Nees Ex Bl. from Five Areas of Indonesia. Pharmacogn J. 2020; May-June, 12(3), pp. 578-588.

9. Dhifi, W. et al. Essential Oils' Chemical Characterization and Investigation of Some Biological Activities: A Critical Review. Medicines. 2016; 22 September.3(25).

10. Xue, Z., Duan , L.-X. \& Qi, X.,. Gas Chromatography Mass Spectrometry Coupling Techniques. In: X. Qi, X. Chen \& Y. Wang, eds. Plant Metabolomics Methods and Applications. Beijing: Springer Dordrecht Heidelberg joint Chemical Industry Press. 2015; pp. 25-44.

11. Al-Dhubiab, B. E. Pharmaceutical Applications and Phytochemical Profile of Cinnamomum burmannii. Pharmacogn Review. 2012; JulDec, 6(12), pp. 125-131.

12. Lemeshow, S. et al. Adequacy of Sample Size in Health Studies. 1990; Baffins Lane, Chichester: John Wiley \& Sons.

13. Vetal, S., Bodhankar, S. L., Mohanb, V. \& Thakurdesai, P. A. Antiinflammatory and Anti-arthritic Activity of type-a Procyanidine Polyphenols from Bark of Cinnamomum zeylanicum in rats. Food Science and Human Wellness, 2013; 2, p. 59-67.

14. Kostadinov, I. Kostadinov, I; Delev, D; Petrova, A; Stanimirova, Irina; Draganova, Krassimira; Kostadinova, Ivanka; Murdjeva, MariannaStudy on Anti-inflammatory and Immunomodulatory Effects of Clomipramine in Carrageenan and Lipopolysaccharideinduce Rat Models of nflamation. Biotechnology \&Biotechnological Equipment. 2014. 25 Sep, 28(3), pp. 552-558.

15. Phanse, M. A. Phanse, Mohini A. ; Patil, Manohar J. ; Abbulu, Konde: Chaudhari, Pravin D. : Patel, Bhoomiet al. In-vivo and in-vitro screening of medicinal plants for their anti-inflammatory activity: an overview. Journal of Applied Pharmaceutical Science. 2012; 02 (07), pp. 19-33.

16. Nile, S. H. \& Park, S. W. Optimized Methods for In Vitro and In Vivo Anti-Inflammatory Assays and Its Applications in Herbal and Synthetic Drug Analysis. Mini-Reviews in Medicinal Chemistry. 2013, 13, pp. 95-100.

17. Nowak, M., Madej, J. A. \& Dziegiel, P., Intensity of COX2 Expression in Cells of Soft Tissue Fibrosarcomas in Dogs as Related to Grade of Tumour Malignancy. Bull Vet Inst Pulawy. 2007; 51, pp. 275-279.

18. Liao, J.-C.et al. Anti-Inflammatory Activities of Cinnamomum cassia Constituents In Vitro and In Vivo. Evidence-Based Complementary and Alternative Medicine. 2012; 2012, Article ID 429320, 12 pages

19. Amdekar, Sarika, et al. Anti-Inflammatory Activity of Lactobacillus on Carrageenan-Induced Paw Edema in Male Wistar Rats. International Journal Inflamation, 2012; 2012, p. 752015.

20. Rocha, A. C. et al. Relevance of Tumour Necrosis Factor-a for the Inflammatory and Nociceptive Responses Evoked by Carrageenan in the Mouse Paw. British Journal of Pharmacology. 2006, 148(5), p. 688-695. 
21. Hosni, A.A; Abdell-Moneim, A.A; Abdel-Reheim, E.S; Mahammed, S.M.; Hel; Helmy, HAdenin, The Role of Inflamatory Components Due to Insertion Contraceptive Devices in the Womb and Its Relationship with Elevated Level of Glycodelin A. eJKI. 2019; Agustus, 7(2), pp. 156-161.
22. Joshi, K.; Awte, S; Bhatnagar P. ; Walunj S. ; Gupta R. Cinnamomum zeylanicum Extract Inhibits Proinflammatory Cytokine TNF $\mu$ : in vitro and in vivo Studies. Research In Pharmaceutical Biotechnology. 2010; April , 2(2), pp. 14-21

\section{GRAPHICAL ABSTRACT}

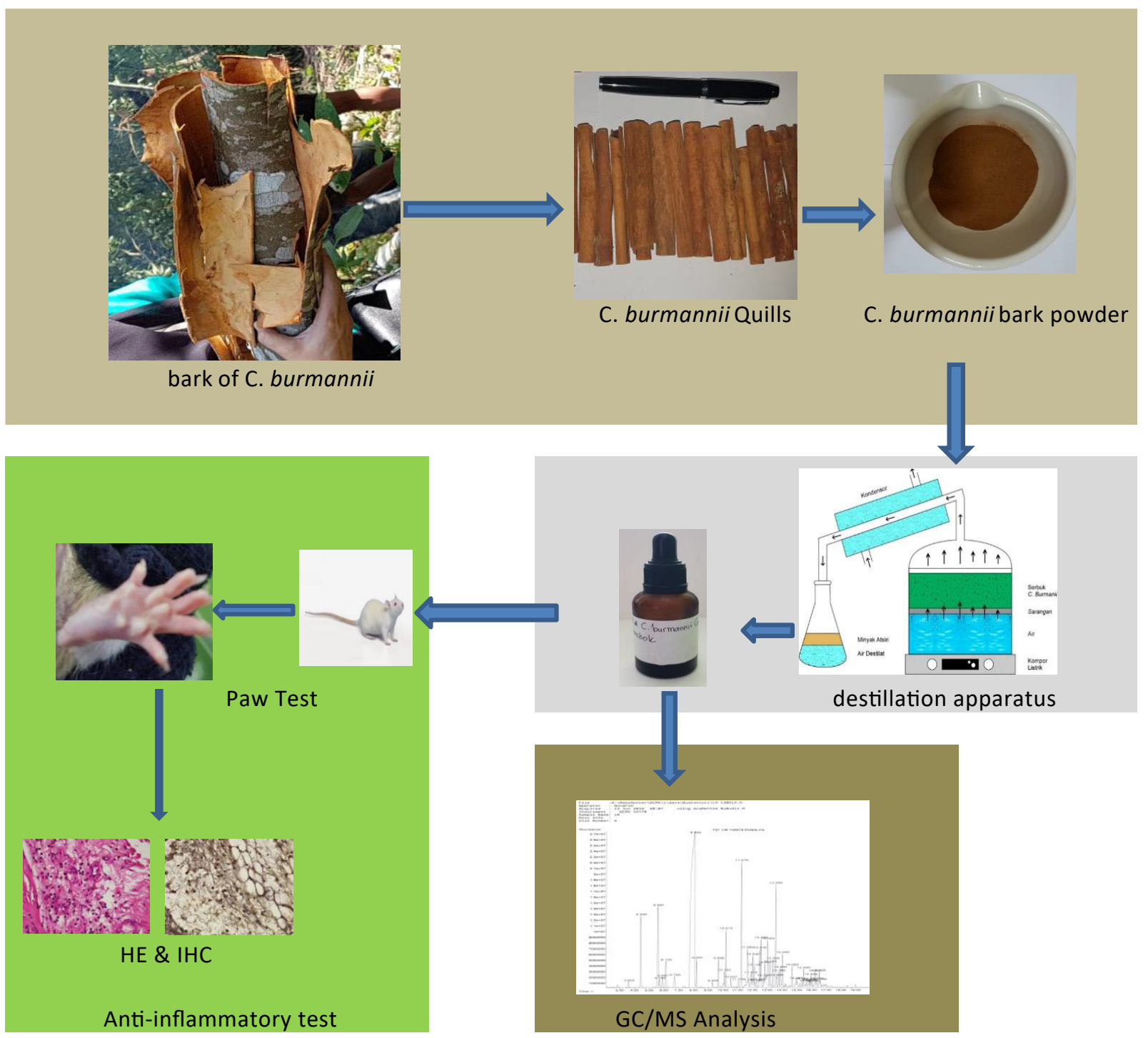




\section{ABOUT AUTHORS}
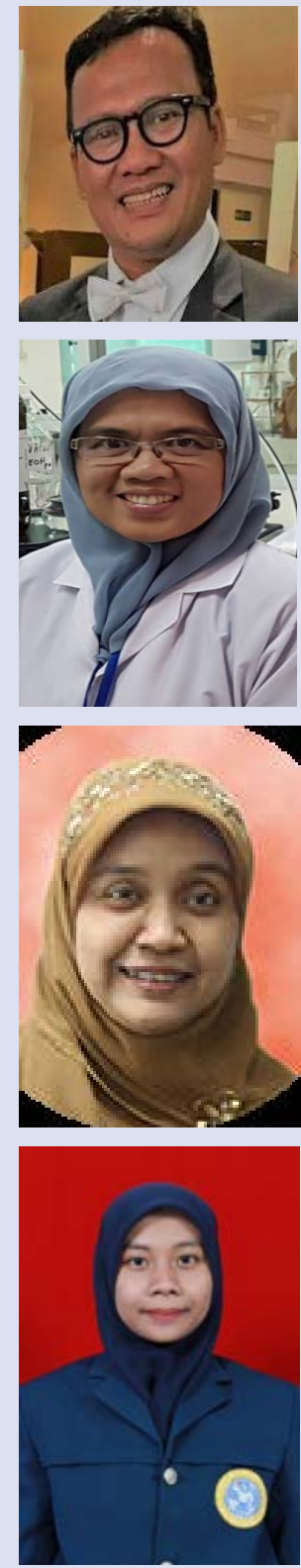

Sukardiman is Professor Pharmacognosy in Department of Pharmaceutical Sciences, Faculty of Pharmacy, Universitas Airlangga, Surabaya, Indonesia. He has vast experience in the area of Pharmacognosy, Natural Product \& Pharmacology. $\mathrm{He}$ has projects in developing Product Antidiabetic, Anticancer from Indonesian Herbal Medicine, and Herbal Standardization. Guiding students for PhD, studies of various Universities. He has publication in National and International Journal.

Budiastuti is a doctoral student on Faculty of Pharmacy, Universitas Airlangga, Surabaya. She has experience on research dealing with essential oil from Cinnamomum burmannii bark for antiinflamation. She also has position as plant manager on herbal medicine industry.

Riesta Primaharinastiti is Doctor on Department of Pharmaceutical Sciences, Faculty of Pharmacy, Universitas Airlangga, Surabaya, Indonesia. Skilled in Research, Analytical Chemistry and Higher Education. Strong education professional with a Doctor focused in Pharmacy from Universitas Airlangga. She works as vice dean for academic affair on Faculty of Pharmacy, Universitas Airlangga, Surabaya.

Rosy Dwi Nurcholida is undergraduated student, Faculty of Pharmacy, Universitas Airlangga. She worked on a doctoral program project in Department of Pharmacognosy and Phytochemistry: Profiling Essential Oils from Cinnamomum burmannii bark and Anti-inflammatory activity in fiscal year 2019.

Cite this article: Budiastuti, Nurcholida RD, Primaharinastiti R, Sukardiman. Anti-Inflammatory Activity of Cinnamon Bark Oil (Cinnamomum burmannii (Nees \& T. Nees) Blume from Lombok Timur Indonesia. Pharmacogn J. 2021;13(4): 1005-1013. 